DOI 10.15290/cnisk.2021.01.10.08

ŁUKASZ JĘDRZEJSKI

https://orcid.org/0000-0002-2632-9117

Unlwersytet Marii Curie-Skłodowskiej w Lublinie

\title{
Source study of the Polish Film Chronicle (1944-1994). Biography of editor-in-chief Helena Lemańska ${ }^{1}$
}

\begin{abstract}
The aim of the scientific article was to present the biography of Helena Lemańska, for many years the editor of Polish Film Chronicle (PFC). The article used two science technique: 1) Exegesis sources, 2) Interview. An interesting theme in the biography of Lemańska was her annual activity of the organization Hashomer Hatzair. Experience in journalism helped her in managing a team of PFC and contributed to the introduction of innovative techniques in the work of the PFC.

Keywords: Helena Lemańska, Polish Film Chronicle, political communication, state system, cultural policy, Polish People's Republic
\end{abstract}

\footnotetext{
Publikacja przygotowana/finansowana w ramach programu Ministra Nauki i Szkolnictwa Wyższego pod nazwą DIALOG w latach 2019-2021. Jest wynikiem udziału w projekcie badawczym pt. „Ośrodek badań historii kobiet”, nr 0016/DLG/2019/10.
} 


\section{ŹRÓDEOWE BADANIE DZIEJÓW POLSKIEJ KRONIKI FILMOWEJ (1944-1994). PRZYPADEK BIOGRAFII REDAKTOR NACZELNEJ HELENY LEMAŃSKIEJ}

\section{Streszczenie}

Celem niniejszego artykułu naukowego jest prezentacja źródłowego badania dziejów Polskiej Rzeczypospolitej Ludowej przez pryzmat biografii redaktor naczelnej Polskiej Kroniki Filmowej Heleny Lemańskiej. W artykule wykorzystano dwie techniki badawcze: 1. egzegezę, 2. technikę wywiadu.

Słowa kluczowe: Helena Lemańska, Polska Kronika Filmowa, komunikowanie polityczne, system państwa, polityka kulturalna, Polska Rzeczpospolita Ludowa

\section{Introductory remarks}

Since the social changes taking place in Poland after 1989, the scientific community has seen an increase in the importance of research on the recent past of the history of Poland in the second half of the 20th century, or more precisely, for the period of the Polish People's Republic (PRL). Increased research activity in the history of recent Poland was a consequence of the feeling of failure to respond to the functioning of Poland's political system in the second half of the 20th century. In the conducted research, historians, political scientists, and sociologists are looking for answers to many questions, including the terminology of the political system, the state identity of the Polish People's Republic, the functioning of the state under the dominance of communist ideology, which was all-encompassing. General factors, such as freeing scientific research from censorship and better access to rich archival resources, also contributed to the deepening interest in the history of the PRL in scientific writing. The state of affairs, as mentioned above, favored the exploration of historical and political science topics that could not be exploited during the Polish People's Republic. The conducted research did not avoid the confrontational nature of publications in which attempts were made to eliminate "white spots" in history, to demand the past, to remember the newly rediscovered account, to redefine existing concepts and general 
phenomena, as well as specific ones, such as changing external allies or seeking a new place in a changing Europe and world. Publications about the People's Republic of Poland revealed awareness of difficulties in the process of a discourse of traumatic events and their processing into memory components ${ }^{2}$.

In social and humanities research in the disciplines of Political Science and Administration and Social Communication and Media, in the subdiscipline of political communication, a new specialization has developed which allows the development of new methods for examining facts relating to the history of Poland in the second half of the 20th century. This enables the synthesis of the historical processes of the PRL.

An interesting source for studying the history of the People's Republic of Poland, which has been under-exploited until recently, has become the Polish Film Chronicle [Pol. Polska Kronika Filmowa - PKF], which is a magazine consisting of accounts and columns published in 1944-1994. The editorial office of the chronicle was established on November 15, 1944, as part of the Polish Army Film Studio located in Lublin. The inauguration of the activity took place on December 1, 1944, and the first editors-in-chief were Jerzy Bossak and Ludwik Perski. Individual issues of the magazine lasted about 10 minutes and contained 8 to 10 topics, although there were more extended special editions. The chronicle was published weekly, and in the years 1957-1980 twice a week. Its broadcast then preceded every cinema screening in Poland. The state authorities imposed propaganda tasks on the editors. Essential functions that the chronicle performed additionally were cognitive and entertainment functions. The attractive form made the magazine very popular. For example, in 1949, the audience of the chronicle was estimated at five million viewers a week. The magazine had a permanent front board with a universally recognizable logotype. The hallmark was also a sound signal composed by Władysław Szpilman ${ }^{3}$.

The chronicle as a source of political science-related cognition had much information about the state's activities in 19441994. The film magazine was a remnant of the deliberate acts of

2 Ewa Maj, Wprowadzenie, in: Ewa Maj, Jerzy Gryz, Eleonora Kirwiel, Marcin Wichmanowski (ed.), PRL, czyli Polska $w$ drugiej połowie XX wieku. Studia i szkice naukowe oraz materiały źródłowe, (Lublin: Wydawnictwo UMCS, 2013), 8.

3 Tadeusz Lubelski (ed.), Encyklopedia kina, (Kraków: Biały Kruk, 2003), passim. 
a man living in a society in 1944-1994. Besides, it became a remnant of the products of social life organization ${ }^{4}$. When studying PKF, a political scientist using various types of political science sources in his research should have solidly proven source knowledge. Researchers acquired the source knowledge contained in PKF through two-dimensional criticism of the source, which is PKF. Source analysis involved two dimensions of external source criticism consisting of determining the external characteristics of the source, origin, degree of authenticity, correctness, and influence. The internal dimension of the criticism of the scientific source referred to the credibility of the source. When examining PKF as a political science source, it was necessary to interpret the source that is the basis for learning the vision of past events presented in the film magazine. It was essential to systematize the source along with the description, formulate an assessment of the degree of usefulness of the content submitted in the source ${ }^{5}$.

Due to the object and subject contained in the scientific narrative, the following question should have been asked in the presented text. Can the documentary film which PKF was undoubtedly a reliable source of knowledge about the past? One had to agree with the statement formulated by Ewa Maj, who claimed that: "The historical source is a text intended for its present-day, then interpreted in subsequent adaptations"6. PKF in post-war Poland has become an element of the universal circulation of media information. Due to the widespread phenomenon of illiteracy prevailing in Poland after the war, its power of influence has been on par with written sources, sometimes exceeding its usefulness due to its full social accessibility. The dimensions of reception, the strength of expression and persuasion, which was confirmed by the dynamics of

\footnotetext{
4 Benon Miśkiewicz, Wstęp do badań historycznych, (Warszawa: Państwowe Wydawnictwo Naukowe, 1974), 114, Jerzy Topolski, Metodologia historii, (Warszawa: Państwowe Wydawnictwo Naukowe, 1973), 334, Maciej Bugajewski, „Świadectwo historiografii”, in: Jolanta Kolbuszewska, Rafał Stobiecki (ed.), Historyk wobec źródeł. Historiografia klasyczna i nowe propozycje metodologiczne, (Łódź: Wydawnictwo Ibidem, 2010), 79-89; Marian Surmaczyński, Podstawowe problemy metodologiczne nauk społeczno-politycznych, (Wrocław: Wydawnictwo Uniwersytetu Wrocławskiego, 2010), 11-35.

5 Jerzy Topolski, „Historyk i źródła: próba dynamicznej charakterystyki źródeł historycznych", in: Jerzy Topolski (ed.), Marksizm i historia, (Warszawa: Państwowy Instytut Wydawniczy, 1977), 47.

$6 \quad$ Ewa Maj, „Źródłowe badanie dziejów Polski Ludowej: przypadek fabularnej twórczości filmowej”, Annales Universitatis Paedagogicae Cracoviensis. Studia Politologica, Vol. 10, 2013, 4.
} 
the development of the cinema network and the number of viewers against the background of the state of reading books and the press in People's Poland. Also, during the period when the editor-in-chief of the film magazine was Helena Lemańska, the contents presented in the film narrative were subject to further interpretations. There were also sometimes layers of meaning in the media coverage. Cinema viewers in the story showed at PKF could find patterns of desirable human behavior present in gestures, symbols, and works of art. PKF was a recording of social and political reality played on film. At first, on black and white tape that in the late 1960s, inscriptions on the colored tape would appear incidentally. Color tape editions were a regular feature of PKF media coverage in the early 1990s.

The article aimed to present the biography and organizational achievements of the long-term editor-in-chief of PKF Helena Lemańska. The following reasons dictated the formulation of the above purpose: 1) The years in which Helena Lemańska (19491967, June) was the editor of PKF were recorded in the history of the magazine as the period of the most intensive and dynamic development of the chronicle. 2) During this period, the editors of the magazine won many prestigious awards at film festivals in the country and abroad. It is surprising, therefore, that the available literature on the subject shows an evident lack of information regarding the activities and professional achievements of Helena Lemańska?

It seemed necessary to formulate several research questions that outlined the shape of the presented considerations. It was worth considering the following issues: 1) What was Lemańska's personality shaped as a result of her childhood and youth experience? 2) What was the magazine's editorial work in 1949-1967? 3)

\footnotetext{
7 The activity of Helena Lemańska as an editor-in-chief of PKF was partially analyzed by Marek Kosma Cieśliński, vide Marek Kosma Cieśliński, "Personalia z historii PKF”, Kino, No. 10, 2000; eadem, "Realizm i kreacja. Redagowanie Polskiej Kroniki Filmowej w latach 1956-1970", Kwartalnik Filmowy, No. 49-50, 2005; eadem, Piękniej niż w życiu. Polska Kronika Filmowa 1944-1994, (Warszawa: Wydawnictwo Trio, 2006). Extended information on Lemańska's activity as editor-in-chief of PKF can be found in the following publications: Łukasz Jędrzejski, Polska Kronika Filmowa 1944-1994. Obrazy komunikowania politycznego, (Doctoral dissertation written under the scientific guidance of Prof. dr hab. Ewy Maj), (Lublin 2019) (Typescript is in the Main Library of Maria Curie Skłodowska University in Lublin, Poland; idem, "Polska Kronika Filmowa w latach 1944-1968 jako medium partyjne. Zarys problemu”, Polityka i Społeczeństwo, No. 1(15), 2017.
} 
In what circumstances did she resign from the function of the editor-in-chief of PKF? The article uses the source exegesis technique and the interview technique ${ }^{8}$. The statements made by Lemańska were complemented by remembrance statements formulated by the excellent editor Jadwiga Zajiček (born in 1925), as well as PKF editor Piotr Halbersztat.

Interviews were conducted with the creators of PKF in a manner appropriate for a casual interview. They took the form of a conversation containing ordered stages of statements such as 1) asking filtering questions, 2) establishing facts, 3) formulating assessments, 4) specifying inquiry and encouraging the speaker to provide in-depth answers, such actions were aimed at determining the lie factor contained in the worded statements, 5) preparation of the final opinion on the implementation of the interlocutor-oriented instruction. When learning the conclusion on information provided by interlocutors, the account had to be taken of objective factors, which included: 1) distorting or concealing facts, 2) not admitting to "uncomfortable" events from the life of the speaker, 2) in some cases, old age callers. Both the interview with Lemańska and the detailed interviews were conducted using the Skype messenger. Contact with Helena Lemańska was possible thanks to the kindness of the editor-in-chief of the periodical "Zeszyty Literackie" by Barbara Toruńczyk - a close friend of Lemańska.

\section{Childhood and early youth}

Helena Lemańska was born around May 15, 1918. She didn't know the exact date of birth. It is possible that her mother, Jadwiga Lemańska, remembered her date of birth, but she died during

\footnotetext{
8 The previously prepared interview questionnaire included the following questions: 1) What factors influenced the expulsion of Helena Lemańska from France when she worked in the editorial office of "Gazeta Polska"? 2) Why did the party and state authorities recommend Helena Lemańska as the editor-in-chief of PKF? 3) What priorities did the party and state authorities set for Helena Lemańska when she became the editor-in-chief of PKF? 4) How to develop a new style in constructing political messages in the chronicle? The significant cognitive value of the chronicle is evidenced by numerous awards won by the editors at many festivals. 5) How did you meet the expectations of the state propaganda apparatus about the content posted in the PKF, and maintain a relatively significant degree of independence in creating political messages in the PKF? 6) What was the work of the chronicle editorial team? 7) What were the circumstances of the dismissal of Ms. Lemanska from the function of the editor-in-chief of PKF?
} 
World War II. Lemańska was born in Warsaw in the Słodowiec district on 28 Marymoncka Street. Her grandfather was a tzadik living in Kock in the Lublin region ${ }^{9}$. Lemańska's father was the Talmudist Mieczysław Lemański. She spent her childhood in one of the rental houses in Warsaw. The house was one-story, without a bathroom and sewage system. Lemańska's father worked in one of Warsaw's manufactories, was a warehouseman, and dealt with accounting. The mother was a seamstress and embroidery ${ }^{10}$. H. Lemańska graduated from elementary school in Warsaw. After graduating from it, she got to the Warsaw junior high school named after Swiatecka. It was a Jewish school with Polish as a lecture language. During that time, she received a scholarship. To improve her budget, she also tutored while in school. In her biography prepared for the party's documentation, she wrote: "I also made a living by giving private tuition after graduating from high school, which I received in $1937^{\prime 11}$. An exciting episode in Lemańska's life in the years 19351936 was membership in the Zionist youth organization Hashomer Hatzair ${ }^{12}$. During the interrogation associated with the growing anti-Zionist campaign in 1968, Helena Lemańska stated: "It was undoubtedly a Zionist organization whose task was to prepare its members for the trip to Palestine. Among the many Jewish organizations that existed at that time, Hashomer Hatzair belonged to their left-wing" ${ }^{13}$.

9 It is another inaccuracy in Lemańska's biography. The SB operational files and the official CVs of Lemańska show that Lemańska's grandfather was a tzadik in Góra Kalwaria.

10 Julia Juryś, "Cadyk z Kocka miał dwie wnuczki”, Zeszyty Literackie, No. 2, 2018, 129.

11 Archiwum Instytutu Pamięci Narodowej [AIPN], IPN/BU-012241682, Życiorys Heleny Lemańskiej [Curriculum vitae of Helena Lemańska], n.pag.

12 Hashomer Hatzair: A Zionist youth organization operating among others in Poland. The organization was also called the "Young Guardian". In 1920-1930, the organization formulated a separate Marxist-Zionist ideology. In 1920-1930, Hashomer Hatzair strictly referred to the assumptions of Marxist doctrine. Many Hashomer Hatzair leaders likened the Soviet Union to their second home. They called the USSR "Socialist Palestine". The management of Hashomer Hatzair postulated to work for a global socialist revolution. Rafael Medoff, Chaim Waxman, "Hashomer Hatzair", in: Rafael Medoff, Chaim Waxman (ed.), The A to Z of Zionism, (New York: The Scarecrow Press, 2013, 76-77, 93).

13 AIPN, IPN/BU-012241682, Protokół z przesłuchania świadka Heleny Lemańskiej [Report on the interrogation of the witness Helena Lemanska], n.pag. During the interrogation, Lemańska also tried to recreate the organizational structure of Hashomer Hatzair: "The organizational character and activities were similar to the scout's organization. As I remember, the basic organizational unit was a kunca grouping 10-12 people. Several kunc formed gdud, and gdud was part of the Warsaw organization Hashomer Hatzair, ibidem. 
After passing her secondary school-leaving examination, in 1938, Helena Lemańska went to study at the University of Jerusalem $^{14}$. Her biography shows that during her studies she worked in the university canteen, peeling vegetables. Besides, she washed the windows for money. As Julia Juryś recalls: "She walked with a bucket of vinegar on the streets of Jerusalem. Who asked her, she washed them"15. She returned to Poland on the eve of the outbreak of World War II in July 1939. Lemańska, in the following words, related her fate during World War II: After the Nazis entered, I went to Lviv, and from there, I went to the village of Aleksandrowskaja, Ordzhonikidze ${ }^{16}$. I went to Lviv in October 1939 with my friend Dora Grab in search of Dora's brothers. During the trip to Lviv, Helena and Dora met with gestures of help from the Germans - for example, soldiers gave them pieces of chocolate. The Jews who had their farms and encountered them on the road to Lviv gave them accommodation and shelter. Helpful in obtaining housing was the fact that the granddaughter of Tzadik from Kock traveled to Lviv. Dora Grab often used this information on the way to the east ${ }^{17}$.

Lemańska and Grab returned from Lviv to Warsaw. During her stay in Ordzhonikidze, Lemańska took up a chauffeur job in one of the state-owned companies and began studying Russian. In 1942 she left Ordzhonikidze and moved to Armenia. In Yerevan, Lemańska graduated from Russian philology at the Pedagogical Institute of Russian Language and Literature. It is worth mentioning that in 1944 Lemańska went to Moscow, where she took up a job at the Polish Press Agency's delegation as a translator-editor. While working at PAP (Polish Press Agency) in Moscow, Lemańska got acquainted with Idalia and Roman Juryś more closely. After the end of World War II, Helena Lemańska returned to Poland in 1946. She took a job at the editorial office of "Głos Ludu"18. While working in

\footnotetext{
14 Helena Lemańska did not provide further information on what faculty she started studying. 15 Julia Juryś, "Cadyk z Kocka”, 131.

16 Currently, Władykaukaz. The largest city and capital of the Republic of North Ossetia-Alania, located in the southern part of the country, at the foot of the Caucasus on the river Terek. When Helena Lemańska left for Ordzhonikidze there was a significant Polish diaspora. AIPN, IPN/BU-012241682, Życiorys Heleny Lemańskiej, n.pag.

17 Julia Juryś, "Cadyk z Kocka”, 135.

18 "It was not an extensive editorial office ... The editorial staff included: Andrzej Weber, Iza Bychowska, Wilhelmina Skulska, Adam Drozdowicz, Helena Lemańska, Roman Juryś, Jerzy Lobman, Mikołaj Wadias”. Helena Zatorska, Spoza smugi cienia - wspomnień ciag dalszy, (Kraków: Wydawnictwo Literackie, 1985), 199.
} 
the newspaper, she was accepted to the Polish Workers' Party. She worked in the editorial office of "Głos Ludu" until January 1949. From January 1949, she was delegated to France to work in "Gazeta Polska". In the following words, Lemańska related her stay in France: "Yes, I worked in "Gazeta Polska", but in France, I resided there as a member of the Chopin Committee. In other words, I stayed in France illegally"19. Helena Lemańska stayed on French territory until October 1949. In her official biography, she stated: "The French authorities did not give reasons for expulsion" ${ }^{20}$. The sources of Lemańska's expulsion from France in 1949 should be traced to the appearance in the political life of Poland and France of the Robineau case ${ }^{21}$. Helena Lemańska said: "They expelled the French consul from Poland. The French expelled many valuable Poles in retaliation". After returning to Poland, Lemańska contacted Roman Werfel. Werfel planned to set up a new magazine. However, the party and state authorities did not agree to the creation of a new magazine. As Julia Juryś stated: "Helena Lemańska returned from Paris to Poland, it was known that she was a journalist (editorial secretary) because she was never a writing journalist. Lemańska was to become the editorial secretary in a new journal because she gained experience in a similar position in "Głos Ludu"22.

\section{As the head of Polish Film Chronicle}

At the beginning of her work at the Documentary and Feature Film Studio at 21 Chełmska Street in Warsaw, Lemańska did not immediately take the position of an independent editor-in-chief. In the beginning, she edited PKF together with Borzechowa. This state of affairs was undoubtedly influenced by the lack of film experience of the future editor-in-chief of PKF. Cieśliński also pointed out the lack of Lemańska's film experience in his research. He wrote:

\footnotetext{
19 Interview with Helena Lemańska conducted on February 11-13, 2016.

20 Ibidem, AIPN, IPN/BU-012241682, Życiorys Heleny Lemańskiej, n.pag.

21 According to the preserved investigation files in the Robineau case, the decision on his temporary arrest was issued on November 30 by the prosecutor of the Supreme Military Prosecutor's Office, Major Mieczysław Dytry. Robineau was charged with committing offenses under Article 7 of the Small Criminal Code. Dariusz Jarosz, Maria Pasztor, "Polsko-francuska "zimna wojna": sprawa Robineau (1949-1950)", Dzieje Najnowsze, No. 3, 2001, 117.

22 Interview with Julia Juryś on February 13, 2016, (private collection of the author).
} 
Lemańska did not have film experience, it was difficult for her to face the mastery of Bossak and Kaźmierczak. Also, joining the party immediately before entering a film studio, she did not have much support from the party apparatus. In the hands of her employers, she was a suitable, passive employee to introduce new orders $^{23}$.

Indeed, in the assumption of state authorities in the early 1950s, the role of the editor-in-chief of PKF was to be significantly marginalized. The editorial office was to be deprived of the margin of independence developed by Bossak used in creating editions. As Cieśliński noted: "The role of the chronicle leader has changed significantly. The place of making the most important decisions was the Propaganda and Press Department of the Central Committee of the Polish United Workers' Party"24.

Lemańska, in the PKF editorial office as editor-in-chief, started to acquire film skills quite quickly. Julia Juryś claimed: "In those days Lemańska was the most talented of the gifted, she learned the film herself, and then she taught others"25. The years 1955-1967 were the period in which the Chronicle celebrated its greatest triumphs in Poland and abroad. The magazine's editors have won many prestigious awards at major film festivals, including the Grand Prix in Cannes (1962) and Oberhausen (1965), which confirmed the professionalism of the work of the creators of the Chronicle ${ }^{26}$.

The successes mentioned were primarily due to Lemańska, who had an excellent knowledge of the people who worked with her. Therefore, Jolanta Lemann is right, when, in one of the articles described the functioning of the editorial office under the management of Lemanska in one of the following words:

Helena Lemańska was a journalist by profession and temperament ..., brilliant, quickly conquered the entire chronicle. She was an energetic ... boss. She liked to surround herself with young, talented people ${ }^{27}$.

23 Marek Cieśliński, Piękniej niż $w$ życiu, 53.

24 Marek Cieśliński, Personalia, 12.

25 Interview with Julia Juryś on February 13, 2016.

26 Tadeusz Lubelski, Encyklopedia kina, 752.

27 Jolanta Lemann, "Czarna seria polskiego dokumentu-kreatorzy i aktorzy", in: Ewelina Nurczyńska-Fidelska, Bronisława Stolarska (ed.), Szkoła polska - powroty, Acta Universitatis Lodziensis: Folia Scientiae Artium et Litterarum, No. 7, 1998, 32. 
Indeed, Lemańska, as the head of PKF, proved to be strict, demanding, but at the same time fair boss. She quickly managed to win over the PKF team, which respected her ${ }^{28}$. The editor-in-chief also mentioned that all responsibility for the preparation of each edition of PKF fell on her. So it was she who decided to set daily tasks for operators" 29 . In one press interview, she stated:

Actually, the entire Polish press is the author of PKF. The use of agency information, a column, or press journalism in our specific chronicle makeover - they give new tensions so unexpected that they have escaped the attention of real authors for so many years ${ }^{30}$.

The information also confirmed J. Zajiček specifying that the editor-in-chief:

... watched over every PKF issue by watching it in the picture and sound editing room. Sometimes it amended, possibly shortened the material, and also adjusted the text ${ }^{31}$.

The single components of the PKF publishing cycle in the 1950s and 1960s included the following elements: 1) designation of materials by individual operators, 2) pre-release screening of a film carried out by Lemańska on the first silent projection, 3) assembly stage after the pre-release screening, 4) textual elaboration, ${ }^{32} 5$ ) PKF musical elaboration (in the 1950s and 1960s, Marek Lusztig was responsible for the selection of musical setting in the PKF editorial team).

\footnotetext{
28 Janina Bauman wrote in her memoirs: "I admired Helena. She was wise and penetrating, she had a sharp eye and a sharp tongue. Although tiny and inconspicuous ..., she aroused respect and trust". Janina Bauman, Nigdzie na ziemi. Powroty, opowiadania, (Eódź: Oficyna, 2011), 110. Jadwiga Zajiček mentioned in her memoirs: "Lemańska was a very good boss. She created a team that treated her with respect. Although sometimes with her non-opposing decisions she aroused fear among colleagues". Interview with Jadwiga Zajiček on February 26, 2016, author's private collection.

29 Interview with Jadwiga Zajiček on February 26, 2016, author's private collection.

30 Krystyna. Garbień, "PKF ma już także dwadzieścia lat”, Film, No. 49, 1964, 7.

31 Interview with Jadwiga Zajiček.

32 Helena Lemańska, in the conversation, mentioned that the authors of the texts were people such as Karol Małcużyński and Jerzy Kasprzycki. Most often, the person responsible for elaborating the PKF text was Małcużyński. Cooperation with him caused many inconveniences, as she mentioned: "Małcużyński was very sick, it happened that I went to Zakopane for a comment form him - he had an irreplaceable 'pen'. It was associated with significant problems. As the editor-in-chief of PKF, I did not have a company car". Interview with Helena Lemańska on February 13-14, 2016, (private collection of the author).
} 
Lemańska mentioned in a private conversation: "We all made up the PKF team, a group of cinematographers, editors, songwriters, music authors, and teachers. Everything was supervised by the head of the editorial office secretariat. She held the whole team with an "iron fist"'33. An exciting matter worth mentioning was the method of obtaining information about the topics that had to be given to employees for implementation. As Lemańska said, the system of acquiring everyday themes for realization was straightforward. The editor-in-chief studied the press daily, usually party's press organs, weeklies, and local newspapers. After getting acquainted with the contents of the press, a short meeting took place, during which the individual topics were allocated for implementation. Another source of information was obtained from directives elaborated at the meetings of the Press Department of the Central Committee of the Polish United Workers' Party.

As M. Cieśliński notes: “... the editor-in-chief received, according to the distribution list, all kinds of ordinances. They were given at meetings of the most critical editorial offices held several times a year" ${ }^{34}$. As Lemańska noted: "While filming important public holidays, no one from the Central Committee could be missed" 35 . It can be seen that the "scenarios' transmitted by the Central Committee's Press Department were very detailed in this matter. From 1955, the political communications constructed by the PKF editorial team began to show the desire to create a new style of connection on the line PKF - society. Lemańska had a lot of merits in this matter. From 1955, the importance of political communications focused on new issues. For example, the fight against ubiquitous political enemies, both objective and subjective, has been replaced with topics on more accessible topics. Much space in PKF was devoted to so-called intervention topics. As Lemańska indicates: "Developing a new style in the chronicle was possible due to constant disputes with censorship. I came to censor every week. Then I created a letter appealing to the Central Committee, and sometimes the letters were effective" 36 . Different visions of reporting political events on the line of the Press Department of the Central Committee of the

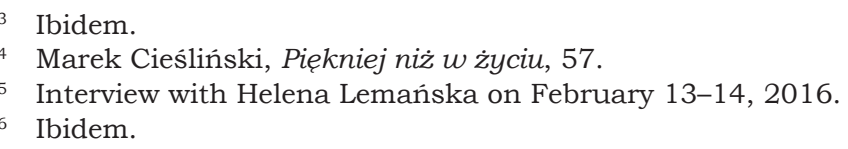


Polish United Workers' Party and the PKF became apparent during the dispute over the Millennium. Lemańska has prepared a chronicle covering the Millennium celebrations in the largest cities in Poland. The representative of the Central Committee unambiguously negatively referred to the content presented in PKF. The comments submitted by the official concerned shots of the crowd of faithful participating in religious services. Lemańska, known for her sharp language, argued the selection of photos for the material presented: "Only an idiot would not let it go in a Catholic country" ${ }^{37}$. In addition to Lemańska's appreciation by the PKF editorial team, an expression of editorial community confidence was entrusted to her function as an executive member (POP) at Wytwórna Filmów Dokumentalnych i Fabularnych [Documentary and Feature Film Studios] in Warsaw. In performing the role of an executive member of the POP WFDiF in Warsaw, she was undoubtedly helped by her extensive contacts in party-state bodies she developed while working in the film studio. As Jolanta Lemann notes: "Lemańska was friends with Rachel Ochabowa and Rita Radkiewicz. For this reason, she was probably well informed about trends in the Politburo and knew what was expected there before others" 38 .

1967 was a breakthrough in Lemańska's life. On April 15, 1967, she organized a projection of PKF from 1956-1957 in the WFDiF auditorium. People associated with the "Commando Group" participated in the screening ${ }^{39}$. During the interrogation, Lemańska said:

I decided for documentary purposes in connection to making a film about the life of the generation that came into adulthood in the 60s to watch several archival film chronicles in 1956-1957. ... Thanks to the presence of young people, I wanted to check the response to the problems raised in the documents ${ }^{40}$.

\footnotetext{
37 Jerzy Eisler, “Millenium 1966”, Więź, No. 5-8, 1989, 111.

38 Jolanta Lemann, "Czarna seria", 138.

39 Julia Juryś and Aleksander Perski took part in the show; a student group of "commandos" gathered around Adam Michnik. Its name was associated with the initial, primary form of activity of group members, i.e., the unexpected appearance of the group at party meetings and youth organizations at which "commandos" asked activists uncomfortable questions. The group existed as an informal community from the mid-1960s to March 1968.

40 AIPN, IPN/BU-012241682, Protokół z przesłuchania Heleny Lemańskiej [Report on the interrogation of Helena Lemańska], n.pag
} 
In 1967, as a result of the outbreak of the Six-Day War, PKF prepared material on Israeli aggression. Karol Małcużyński and Jerzy Kasprzycki made the narration. Helena Lemańska refused to participate in the beginning of anti-Zionist campaign. The Security Service's note about Lemańska reads:

Lemańska tried to soften the text, but the Central Office for the Control of Publications and Publications Press rejected it and amended it. For this reason, Lemańska was much perplexed that Israel was condemned as an aggressor by the party leadership and the PRL government ${ }^{41}$.

It is also worth referring to the memories of Lemańska from the described period. She recalled:

During the Six-Day War, the authorities demanded the anti-Israeli, anti-Semitic position of the chronicle and the language used in it. I refused to participate at the beginning of the anti-Israeli read anti-Semitic campaign. I gave my resignation to minister Tadeusz Zorski. It was not yet the outbreak of anti-Semitism of 1968. The film studio did want to make a big deal about it. I was formally transferred to the documentary department ${ }^{42}$.

Deputy Minister Tadeusz Zaorski accepted the resignation of Helena Lemańska on July 31, $1967^{43}$. As Lemańska mentioned, she was consciously moved to the director's position to avoid a scandal ${ }^{44}$.

However, dismissal from the function of the editor-in-chief of PKF and transferring to the position of director did not escape the representatives of the political class of the time. Mieczyslaw Franciszek Rakowski wrote in his diaries on July 7, 1968:

Helena Lemańska, an excellent editor-in-chief of the Polish Film Chronicle, a righteous human been, bravely defending the high level of the Chronicle against unnecessary trash, she resigned.

\footnotetext{
41 AIPN, IPN/BU-012241682, Notatka dotycząca Heleny Lemańskiej [Note regarding Helena Lemańska], n.pag

42 Interview with Helena Lemańska on February 13-14, 2016.

43 In the work files of Helena Lemańska there is a letter from Deputy Minister Tadeusz Zaorski addressed to the Director of Documentary and Feature Film Studio in Warsaw, Zygmunt Kniaziołucki, AIPN, IPN/BU-012241682, Pismo Tadeusza Zaorskiego do Zygmunta Kniaziałuckiego dotyczace Heleny Lemańskiej [Letter from Tadeusz Zaorski to Zygmunt Kniaziołucki regarding Helena Lemańska], n.pag.

44 Interview with Helena Lemańska on February 13-14, 2016.
} 
Apparently, she said that she could not agree to the censorship dictating what materials she posted in the Chronicle. In my opinion, she did wrong, because those are just waiting for such demonstrations. Now they appoint some "zero", but their man ${ }^{45}$.

So after more than eighteen years, history has come full circle again. As in 1949, party and state authorities effectively got rid of the first PKF editor Jerzy Bossak, so in 1967 Helena Lemańska dismissed the function of PKF editor during the anti-Zionist campaign.

After finishing work in the editorial board of PKF, Lemańska made another film at WFDiF called "Letters from Poland". The production of the movie at the film studio received an excellent note $^{46}$. As a result of the intensifying anti-Zionist campaign in Poland, she was removed from the PZPR at a POP meeting on May 20, 1968. The management of the film studio terminated the employment contract with Lemańska on August 31, 1968, arguing that she would be dismissed as follows: "During her work at the WFDiF, she showed her inability to live with her co-workers ... In connection to take the side of Israel, she was dismissed"47. After dismissal, Lemańska wrote numerous appeals against the management's decision to dismiss her. The letters did not bring positive results. Helena Lemańska's removal was also noticed abroad. It can be presumed that the above situation was caused by extensive foreign contacts, which Lemańska developed over the years of

\footnotetext{
45 Mieczysław Franciszek Rakowski, Dzienniki polityczne, (Warszawa: Wydawnictwo Iskry, 1999), 70-71.

46 While working at WFDiF, Helena Lemańska allowed herself to meet as a person solidly performing the duties entrusted to her. The recognition of Lemańska was granted by the following state decorations: in 1952 - Silver Cross of Merit, in 1954 the Golden Cross of Merit, in 1961 Knight's Cross of the Order of Polonia Restituta, AIPN, IPN/BU-012241682, Opinia dyrekcji Wytwórni Filmów Dokumentalnych i Fabularnych w Warszawie dotycząca Heleny Lemańskiej [Opinion of the Directorate of Documentary and Feature Film Studio in Warsaw regarding Helena Lemańska], n.pag.

47 Helena Lemańska, through the Trade Union of Culture and Art Workers, appealed against the decision of dismissing, justifying the complaint with her long experience in employment, editing and directing positions, as well as her considerable achievements and relevant qualifications, AIPN, IPN/BU-012241682, Związek Zawodowy Pracowników Kultury i Sztuki Zarzą Okręgowy w Warszawie. Skarga Heleny Lemańskiej: Zatrudnionej w Wytwórni Filmów Dokumentalnych i Fabularnych w Warszawie do Podsekretarza Stanu w Ministerstwie Kultury i Sztuki Czesława Wiśniewskiego [Trade Union of Culture and Art Workers District Board in Warsaw. Complaint by Helena Lemańska: Employed at the Documentary and Feature Film Production Company in Warsaw to the Undersecretary of State at the Ministry of Culture and Art Czesław Wiśniewski], n.pag. Lemańska also sent a letter to legal advisor Zygmunt Gassecki asking for the protection of her employee rights.
} 
work at WFDiF. Let this be confirmed by the fact that the Dutch Filmmakers Association protested against Lemańska's dismissal. The secret note of Division I of Department III of the Ministry of Internal Affairs of the Polish People's Republic reads: "The Dutch Filmmakers Association protested in a letter to the Chairman of the Council of State of the People's Republic of Poland against the removal of Jerzy Bossak, Jerzy Toeplitz and Helena Lemańska from the positions" 48 .

Lemańska left Poland in the autumn of 1968. With the help of Idalia Juryś, employees of the Polish embassy in Vienna managed to get to Vienna. In Austria, she met with the director of Pathé Cinéma. She emigrated to France, where she took up work at the French film studio Pathé Cinéma. In Paris, she was received as an outstanding specialist in film archival science. She never did news ${ }^{49}$. After the liquidation of the chronicle, she took a job at the Albert Khan foundation. In recent years, she has said that she feels impatient with her long life: "I am waiting and waiting on this platform, and the train does not come" ${ }^{50}$. Lemańska died on November 21, 2017, in Paris. She was 98 years old.

\section{Summary}

There is no doubt that the operation of PKF in 1944-1994 became a cultural phenomenon. The popularity of PKF was undoubtedly influenced by the team management model developed over the years by the editor-in-chief of H. Lemańska. Lemańska's activity has not been thoroughly researched yet. Exploration of available source materials allowed us to draw the following partial conclusions. The experience of Lemańska's early youth and the education acquired during the war allowed Lemańska to possess a good knowledge of foreign languages enabling her to work freely abroad. Lemańska did not have specialist journalistic education. Like most

\footnotetext{
48 AIPN, IPN/BU-012241682, Wyciag z informacji Wydziału I Departamentu III z zachodnich rozgłośni radiowych $z$ dnia 3 sierpnia 1968 [Statement taken from the information of Divisio I of Department III from Western radio stations, August 3, 1968], n.pag.

49 Tadeusz Sobolewski, "Nie żyje Helena Lemańska, "wielka dama polskiej kinematografii". To Ona stała za Polską Kroniką Filmową. Miała 98 lat”, Gazeta Wyborcza [online] [accessed: 16.03.2020], <https://wyborcza.pl/7,101707,22699177,nie-zyje-helena-lemanska-wielkadama-polskiej-kinematrografii.html>.

50 Ibidem.
} 
people at that time, she was self-taught in the journalism industry. Lemańska also had no film education. However, stubbornness, diligence, and the ability and character of the editor-in-chief of PKF allowed gaining her respect among employees of the Documentary and Feature Film Studio. While serving as the editor-in-chief of PKF, Lemańska proved to be a strict and demanding boss appreciating the artistry of employees. She did not hide her involvement in political matters, which allowed her to adapt to the job requirements set by the state authorities. Lemańska has developed a recognized PKF style in Poland and the world. The editorial team's efforts were appreciated by the awards granted at industry film festivals. The years 1967-1968 were a turning point in the life of the editor-in-chief. Due to the anti-Zionist campaign expanding in the Polish United Workers' Party (PZPR) and throughout Poland, she was dismissed from the function of the editor-in-chief of PKF, then transferred to the position of director at WFDiF in 1968 to be fired from the job by the film studio's authorities. Like many cultural personalities of Jewish origin were forced to leave Poland in 1968.

\section{Bibliography}

\section{Sources}

\section{Archival files}

Archiwum Instytutu Pamięci Narodowej [AIPN], IPN/BU-01224 1682, Życiorys Heleny Lemanskiej [Curriculum vitae of Helena Lemańska].

AIPN, IPN/BU-012241682, Pismo Tadeusza Zaorskiego do Zygmunta Kniaziołuckiego dotyczące Heleny Lemańskiej [Letter from Tadeusz Zaorski to Zygmunt Kniaziołucki regarding Helena Lemańska].

AIPN, IPN/BU-012241682, Notatka dotycząca Heleny Lemańskiej [Note regarding Helena Lemańska].

AIPN, IPN/BU-012241682, Opinia dyrekcji Wytwórni Filmów Dokumentalnych I Fabularnych w Warszawie dotycząca Heleny Lemańskiej [Opinion of the Directorate of Documentary and Feature Film Studio in Warsaw regarding Helena Lemanska].

AIPN, IPN/BU-012241682, Protokół przesłuchania świadka Heleny Lemańskiej [Report on the interrogation of the witness Helena Lemańska]. 
AIPN, IPN/BU-012241682, Wyciag $z$ informacji Wydziału I Departamentu III $z$ zachodnich rozgłośni radiowych $z$ dnia 3 sierpnia 1968 [Statement taken from the information of Divisio I of Department III from Western radio stations, August 3, 1968].

AIPN, IPN/BU-012241682, Związek Zawodowy Pracowników Kultury i Sztuki Zarząd Okręgowy w Warszawie. Skarga Heleny Lemańskiej: Zatrudnionej w Wytwórni Filmów Dokumentalnych i Fabularnych w Warszawie do Podsekretarza Stanu w Ministerstwie Kultury i Sztuki Czesława Wiśniewskiego [Trade Union of Culture and Art Workers District Board in Warsaw. Complaint by Helena Lemanska: Employed at the Documentary and Feature Film Production Company in Warsaw to the Undersecretary of State at the Ministry of Culture and Art Czesław Wiśniewski].

Political journals, political journalism, diaries memories, correspondence, interviews

Bauman, Janina. Nigdzie na ziemi, opowiadania, powroty, (Łódź: Oficyna, 2011).

Interview with Helena Lemańska conducted on February 11-13, 2016, (author's private collection).

Interview with Jadwiga Zajiček on February 26, 2016, (author's private collection).

Interview with Julia Juryś on February 13, 2016, (author's private collection).

Juryś, Julia. "Cadyk z Kocka miał dwie wnuczki”, Zeszyty Literackie, No. 2, 2018, 139-160.

Rakowski, Mieczysław Franciszek. Dzienniki polityczne, (Warszawa: Wydawnictwo Iskry, 1999).

Zatorska, Helena. Spoza smugi cienia - wspomnień ciag dalszy, (Kraków: Wydawnictwo Literackie, 1985).

\section{Press journalism}

Eisler, Jerzy. "Millenium1966", Więź, No. 5-8,1989, 27-37.

\section{Scientific studies}

\section{Dictionary and encyclopedic publications}

Lubelski, Tadeusz. Encyklopedia kina, (Kraków: Wydawnictwo Biały Kruk, 2003). 
Medoff, Rafael, Waxman, Chaim. Hashomer Hatzair, in: Rafael Medoff, Chaim Waxman (ed.), The A to $Z$ of Zionism, (New York: The Scarecrow Press, 2013), 45-60.

\section{Monographs and collective studies}

Bugajewski, Maciej. "Świadectwo historiografii", in: Jolanta Kolbuszewska, Rafał Stobiecki (ed.), Historyk wobec źródeł. Historiografia klasyczna i nowe propozycje metodologiczne, (Łódź: Wydawnictwo Ibidem, 2010), 225-240.

Cieśliński, Marek. Piękniej niż w życiu. Polska Kronika Filmowa 1944-1994, (Warszawa: Wydawnictwo Trio, 2006).

Maj, Ewa. Wprowadzenie, in: Ewa Maj, Jerzy Gryz, Eleonora Kirwiel, Marcin Wichmanowski (ed.), PRL, czyli Polska $w$ drugiej połowie $X X$ wieku. Studia i szkice naukowe oraz materiały źródłowe, (Lublin: Wydawnictwo UMCS, 2013), 7-13.

Miśkiewicz, Benon. Wstęp do badań historycznych, (Warszawa: Państwowe Wydawnictwo Naukowe, 1974).

Surmaczyński, Marian. Podstawowe problemy metodologiczne nauk społeczno-politycznych, (Wrocław: Wydawnictwo Uniwersytetu Wrocławskiego, 2010).

Topolski, Jerzy. Historyk i źródła: próba dynamicznej charakterystyki źródeł historycznych, in: Jerzy Topolski (ed.), Marksizm i historia, (Warszawa: Państwowy Instytut Wydawniczy, 1977).

Topolski, Jerzy. Metodologia historii, (Warszawa: Państwowe Wydawnictwo Naukowe, 1973).

\section{PhD thesis not published}

Jędrzejski, Łukasz. Polska Kronika Filmowa 1944-1994. Obrazy komunikowania politycznego, (Doctoral dissertation written under the scientific guidance of Prof. dr hab. Ewa Maj, Lublin 2019) (Typescript is in the Main Library of Maria Curie Skłodowska University in Lublin, Poland).

\section{Articles in periodicals and scientific series}

Jarosz, Dariusz, Pasztor, Maria. "Polsko-francuska "zimna wojna": sprawa Robineau (1949-1950)", Dzieje Najnowsze, No. 3, 2001, 99-128.

Jędrzejski, Łukasz. "Polska Kronika Filmowa w latach 19441968 jako medium partyjne. Zarys problemu", Polityka i Społeczeństwo, No. 1(15), 2017. 
Lemann, Jolanta. "Czarna seria polskiego dokumentu - kreatorzy i aktorzy", w: Ewelina Nurczynnska-Fidelska, Bronisława Stolarska (ed.), Szkoła polska - powroty, Acta Universitatis Lodziensis: Folia Scientiae Artium et Litterarum, No. 7, 1998, 145-163.

Maj, Ewa. "Źródłowe badanie dziejów Polski Ludowej: przypadek fabularnej twórczości filmowej”, Annales Universitatis Paedagogicae Cracoviensis. Studia Politologica, Vol. 10, 2013, 3-23.

\section{Articles in film magazines}

Cieśliński, Marek Kosma. "Personalia $z$ historii PKF", Kino, No. 10, 2000, 10-15.

Cieśliński, Marek Kosma. "Realizm i kreacja. Redagowanie Polskiej Kroniki Filmowej w latach 1956-1970", Kwartalnik Filmowy, No. 49-50, 2005, 104-129.

Garbień, Krystyna. "PKF ma już także dwadzieścia lat", Film, No. 49, 1964, 5-8.

\section{Websites}

Sobolewski, Tadeusz. "Nie żyje Helena Lemańska, "wielka dama polskiej kinematografii". To Ona stała za Polską Kroniką Filmowa. Miała 98 lat", Gazeta Wyborcza, [online] [accessed: 16.03.2020], <https: / / wyborcza.pl/7,101707,22699177, nie-zyje-helena-lemanska-wielka-dama-polskiej-kinematrografii.html>. 